\title{
Characterization of Cobalt Oxide Nanoparticles Prepared by the Thermal Decomposition of $\left[\mathrm{Co}\left(\mathrm{NH}_{3}\right)_{5}\left(\mathrm{H}_{2} \mathrm{O}\right)\right]\left(\mathrm{NO}_{3}\right)_{3}$ Complex and Study of Their Photocatalytic Activity
}

\author{
Saeed Farhadi,* Masoumeh Javanmard and Gholamali Nadri \\ Department of Chemistry, Lorestan University, Khoramabad 68135-465, Iran \\ * Corresponding author: E-mail: sfarhadi1348@yahoo.com \\ Tel.: +9806633120611, fax: +9806633120618
}

Received: 29-01-2016

\begin{abstract}
In this work, thermal decomposition of the $\left[\mathrm{Co}\left(\mathrm{NH}_{3}\right)_{5}\left(\mathrm{H}_{2} \mathrm{O}\right)\right]\left(\mathrm{NO}_{3}\right)_{3}$ precursor complex was investigated under solid state conditions. Thermal analysis (TG/DTA) showed that the complex was easily decomposed into the $\mathrm{Co}_{3} \mathrm{O}_{4}$ nanoparticles at low temperature $\left(175^{\circ} \mathrm{C}\right)$ without using any expensive and toxic solvent or a complicated equipment. The obtained product was identified by X-ray diffraction (XRD), Fourier transform infrared spectroscopy (FT-IR), Raman spectroscopy, scanning electron microscopy (SEM), transmission electron microscopy (TEM) and energy-dispersive X-ray spectroscopy (EDX). Optical and magnetic properties of the products were studied by UV-visible spectroscopy and a vibrating sample magnetometer (VSM), respectively. FT-IR, XRD and EDX analyses confirmed the formation of highly pure spinel-type $\mathrm{Co}_{3} \mathrm{O}_{4}$ phase with cubic structure. SEM and TEM images showed that the $\mathrm{Co}_{3} \mathrm{O}_{4}$ nanoparticles have a sphere-like morphology with an average size of $17.5 \mathrm{~nm}$. The optical absorption spectrum of the $\mathrm{Co}_{3} \mathrm{O}_{4}$ nanoparticles showed two band gaps of 2.20 and $3.45 \mathrm{eV}$, which in turn confirmed the semiconducting properties. The magnetic measurement showed a weak ferromagnetic order at room temperature. Photocatalytic degradation of methylene blue (MB) demonstrated that the as-prepared $\mathrm{Co}_{3} \mathrm{O}_{4}$ nanoparticles have good photocatalytic activity under visible-light irradiation.
\end{abstract}

Keywords: $\mathrm{Co}_{3} \mathrm{O}_{4}$ nanoparticles, Thermal decomposition, pentamminecobalt(III) complexes, Ferromagnetic order, Photocatalytic degradation.

\section{Introduction}

Transition metal oxide nanoparticles represent an important class of inorganic nanomaterials that have been investigated extensively due to their interesting catalytic, electronic, and magnetic properties relative to those of the bulk counterparts, and wide scope of their potential applications. ${ }^{1}$ Among them, spinel-type cobalt oxide $\left(\mathrm{Co}_{3} \mathrm{O}_{4}\right)$ as a versatile semiconducting material has achievable applications in gas sensors, ${ }^{2,3}$ heterogeneous catalysts, ${ }^{4-6}$ electrochemical devices, ${ }^{7}$ Li-ion batteries,${ }^{8-11}$ magnetic materials $^{12,13}$ and photocatalysts. ${ }^{14,15}$ In recent years, the increasing interest has been focused on the synthesis of $\mathrm{Co}_{3} \mathrm{O}_{4}$ nanostructures because of the influences of particle size on their properties and applications. ${ }^{16-26}$ Various wetchemical methods such as hydro-/solvothermal method, ${ }^{27,28}$ combustion method, ${ }^{29-31}$ microwave heating, ${ }^{32-34}$ sol-gel process, ${ }^{35}$ spray pyrolysis ${ }^{36}$ sonochemical method, ${ }^{37}$ co-precipitation, ${ }^{38}$ ionic liquid-assisted method, ${ }^{39}$ polyol method ${ }^{40}$ and a non-aqueous route ${ }^{41}$ have been reported to synthesize $\mathrm{Co}_{3} \mathrm{O}_{4}$ nanostructures. Nevertheless, most of these methods involve complex processes, high calcination temperatures, and expensive and toxic precursors. In addition to these, they are either time consuming or require expensive instruments.

One of the simplest and lowest cost techniques to prepare metal oxide nanostructures is the solid-state thermal decomposition of molecular precursors. This promising technique offers several unique advantages and significant merits over other methods including easy workup, relatively short reaction time, and the preparation of various inorganic nanomaterials with unique sizes, specific shapes and narrow size distribution. ${ }^{42-46}$ In this context, several precursors including $\mathrm{CoC}_{2} \mathrm{O}_{4} \cdot 2 \mathrm{H}_{2} \mathrm{O},{ }^{47}\left[\mathrm{Co}(\mathrm{Pht})\left(\mathrm{H}_{2} \mathrm{O}\right)\right]_{\mathrm{n}}$ 
polymer, ${ }^{48} \mathrm{Co}$ (salophen $){ }^{49} \quad \mathrm{Co}\left(\mathrm{C}_{6} \mathrm{H}_{5} \mathrm{COO}\right)\left(\mathrm{N}_{2} \mathrm{H}_{4}\right)_{2},{ }^{50}$ $\left[\mathrm{Co}\left(\mathrm{NH}_{3}\right)_{5}\left(\mathrm{CO}_{3}\right)\right]\left(\mathrm{NO}_{3}\right)_{2},{ }^{51}\left[\mathrm{Co}{ }^{\mathrm{III}}\left(\mathrm{NH}_{3}\right)_{6}\right]\left(\mathrm{NO}_{3}\right)_{3},{ }_{5}$ and $\left[\mathrm{Co}\left(\mathrm{NH}_{3}\right)_{6}\right]_{2}\left(\mathrm{C}_{2} \mathrm{O}_{4}\right)_{3} \cdot 4 \mathrm{H}_{2} \mathrm{O}^{53}$ have been used to synthesize $\mathrm{Co}_{3} \mathrm{O}_{4}$ nanostructures via the thermal decomposition route by us and other research groups. However, some of these precursors still are associated with one or more disadvantages, such as prolonged reaction times $(\geq 2 \mathrm{~h})$, high-temperature requirement $\left(\geq 250{ }^{\circ} \mathrm{C}\right)$, use of toxic and expensive organic solvents (e.g. n-hexylamine), and use of surfactants (e.g. oleic acid, SDS and trioctylphosphine oxide). From a practical viewpoint, the development of a simple and new precursor for the synthesis of $\mathrm{Co}_{3} \mathrm{O}_{4}$ nanoparticles at lower temperatures and shorter reaction times is still an active area of research.

In the present work, we wish to report on the direct thermolysis of an energetic pentamminecobalt(III) complex, $\left[\mathrm{Co}\left(\mathrm{NH}_{3}\right)_{5}\left(\mathrm{H}_{2} \mathrm{O}\right)\right]\left(\mathrm{NO}_{3}\right)_{3}$, which led to the synthesis of $\mathrm{Co}_{3} \mathrm{O}_{4}$ nanoparticles at low temperature $\left(175^{\circ} \mathrm{C}\right)$ without needs expensive and toxic solvents or complicated equipment. The obtained $\mathrm{Co}_{3} \mathrm{O}_{4}$ nanoparticles were characterized by X-ray diffraction (XRD), Fourier transform infrared spectroscopy (FT-IR), Raman spectroscopy, scanning electron microscopy (SEM), energy-dispersive X-ray spectroscopy (EDX), transmission electron microscopy (TEM), UV-visible spectroscopy, and magnetic measurement. The method is a fast, mild, energy-efficient and environmentally friendly route to produce $\mathrm{Co}_{3} \mathrm{O}_{4}$ nanoparticles in only one step.

\section{Experimental}

\section{1. Preparation of $\left[\mathrm{Co}\left(\mathrm{NH}_{3}\right)_{5}\left(\mathrm{H}_{2} \mathrm{O}\right)\right]\left(\mathrm{NO}_{3}\right)_{3}$ precursor}

The precursor $\left[\mathrm{Co}\left(\mathrm{NH}_{3}\right)_{5}\left(\mathrm{H}_{2} \mathrm{O}\right)\right]\left(\mathrm{NO}_{3}\right)_{3}$ was synthesized according to the literature method. ${ }^{54}$ Briefly, 10 grams of carbonatopentamminecobalt (III) nitrate $(0.036 \mathrm{~mol})$ was suspended in $25 \mathrm{~mL}$ of water, and $20 \mathrm{~mL}$ of 1:1 nitric acid and water solution was added with stirring. When the evolution of carbon dioxide has stopped (10 minutes), 100 $\mathrm{ml}$. of ethanol is added. The red precipitate of aquopentamminecobalt(II1) nitrate, $\left[\mathrm{Co}\left(\mathrm{NH}_{3}\right)_{5}\left(\mathrm{H}_{2} \mathrm{O}\right)\right]\left(\mathrm{NO}_{3}\right)_{3}$, is collected on a paper filter, washed with alcohol and ether, and then dried in air. Yield: $86 \%$. The composition of the complex was confirmed by thermal analysis, FT-IR, and elemental analysis: Anal. calc. for $\left[\mathrm{Co}\left(\mathrm{NH}_{3}\right)_{5}\left(\mathrm{H}_{2} \mathrm{O}\right)\right]\left(\mathrm{NO}_{3}\right)_{3}$ : Co, 16.93; H, 4.92; N, 32.19; found: Co, 16.84; H, 4.85; N, 32.08 .

\section{2. Preparation of $\mathrm{Co}_{3} \mathrm{O}_{4}$ Nanoparticles}

In order to prepare $\mathrm{Co}_{3} \mathrm{O}_{4}$ nanoparticles, $2 \mathrm{~g}$ of the $\left[\mathrm{Co}\left(\mathrm{NH}_{3}\right)_{5}\left(\mathrm{H}_{2} \mathrm{O}\right)\right]\left(\mathrm{NO}_{3}\right)_{3}$ complex powder in a porcelain crucible was placed in a muffle furnace. The sample was heated at the rate of $10{ }^{\circ} \mathrm{C} \mathrm{min}-1$ from room temperature to $150{ }^{\circ} \mathrm{C}$ in air and was maintained at this temperature for $1 \mathrm{~h}$. Similar experiment was performed for the sample calcined at the selected temperature of $175^{\circ} \mathrm{C}$. The temperatures for calcining the complex were selected from the TG-DTA data (Figure 1). The black product generated from the complex at each temperature was cooled to room temperature and collected for characterization.

\section{3. Methods of Characterization}

Thermal analysis was conducted with a Netzsch STA 409 PC/PG thermal analyzer at a constant heating rate of $10{ }^{\circ} \mathrm{C} \mathrm{min}^{-1}$ in air. The composition and phase purity of the products were characterized by a Rigaku D/max C III X-ray diffractometer using $\mathrm{Ni}$-filtered $\mathrm{Cu}$ Ka radiation $(\lambda=1.5406 \AA)$. XRD patterns were recorded in the $2 \theta$ range of $10^{\circ}-80^{\circ}$ with a scanning step of $0.02^{\circ}$. To investigate chemical bonding of the products, infrared spectra were recorded on the diluted samples in $\mathrm{KBr}$ pellets using a Schimadzu 160 FT-IR spectrophotometer within the region of $4000-400 \mathrm{~cm}^{-1}$. The optical absorption spectrum was recorded on a Shimadzu 1650PC UV-vis spectrophotometer in a wavelength range of $200-700 \mathrm{~nm}$ at room temperature. The samples for UV-vis studies were well dispersed in distilled water by sonication for $30 \mathrm{~min}$ to form a homogeneous suspension. The morphology of $\mathrm{Co}_{3} \mathrm{O}_{4}$ nanoparticles was studied with a Mira3 Tescan field emission scanning electron microscope. The particle sizes of the as-prepared product were observed with a transmission electron microscope (TEM, Philips CM10) and equipped with an energy dispersive X-ray spectroscopy. For the TEM measurements, the powders were ultrasonicated in ethanol and a drop of the suspension was dried on a carbon-coated microgrid. Raman spectrum was obtained using a Thermo Fisher DXR with a laser wavelength of $780 \mathrm{~nm}$ and a spot size of $0.5 \mathrm{~nm}$. The magnetic properties of $\mathrm{Co}_{3} \mathrm{O}_{4}$ nanoparticles were measured using a vibrating sample magnetometer (VSM, Iran Meghnatis Daghigh Kavir Company).

\section{4. Photocatalytic Tests}

$50 \mathrm{ml}$ of $25 \mathrm{mg} / \mathrm{L}$ methylene blue (MB) aqueous solution was used for the photocatalytic experiment. $30 \mathrm{mg}$ of the $\mathrm{Co}_{3} \mathrm{O}_{4}$ nanoparticles were added to $\mathrm{MB}$ aqueous solution and stirred with a magnetic stirrer in the dark for 30 min to establish adsorption-desorption equilibrium between the solution and catalyst prior to the irradiation from the $400 \mathrm{~W}$ high-pressure Mercury lamp $(\lambda \geq 420 \mathrm{~nm})$. After adding $2 \mathrm{~mL}$ of $30 \% \mathrm{H}_{2} \mathrm{O}_{2}$ to the suspension, the lamp was turned on. Samples were taken out and the changes of MB concentration were monitored using a UV-vis spectrometer. At regular time intervals, $5 \mathrm{ml} \mathrm{MB}$ aqueous solution was taken out from the reactor vessel and centrifuged to separate the solution and the suspended catalyst. The 
UV-vis adsorption spectrum of the filtered solution was measured in the range 400-800 $\mathrm{nm}$. The degradation degree of $\mathrm{MB}$ in the aqueous solution was estimated by the absorbance measurements at about $665 \mathrm{~nm}$. All the aqueous samples were at natural $\mathrm{pH}$ and all experiments were carried out at room temperature.

\section{Results and Discussion}

\section{1. Characterization of $\mathrm{Co}_{3} \mathrm{O}_{4}$ Nanoparticles}

Thermal behavior of the $\left[\mathrm{Co}\left(\mathrm{NH}_{3}\right)_{5}\left(\mathrm{H}_{2} \mathrm{O}\right)\right]\left(\mathrm{NO}_{3}\right)_{3}$ precursor was studied by thermal analysis in the temperature range of $25-600{ }^{\circ} \mathrm{C}$. The DTA and TG curves in Fig. 1 show the decomposition of complex proceeds in two stages. In first stage, a small endothermic peak occurred at about $100{ }^{\circ} \mathrm{C}$ and shows about $5.25 \%$ weight-loss which is consistent with the theoretical value of $5.17 \%$ caused by the loss of one molecule of $\mathrm{H}_{2} \mathrm{O}$ per one molecule of complex and the formation of $\left[\mathrm{Co}\left(\mathrm{NH}_{3}\right)_{5}\left(\mathrm{NO}_{3}\right)\right]\left(\mathrm{NO}_{3}\right)_{2} \cdot{ }^{54} \mathrm{In}$ second stage, the residue gives a sharp exothermic peak at about $175{ }^{\circ} \mathrm{C}$ with an extensive weight loss $(72 \%)$ which related to the explosive decomposition of the complex via an intramolecular redox process occurring between the $\mathrm{NH}_{3}$ ligands as reducing agents and the $\mathrm{NO}_{3}{ }^{-}$ions as oxidizing agents. Above $175^{\circ} \mathrm{C}$, the weight remained constant, confirming the complete decomposition of the complex. The weight loss of two steps to be about $77.25 \%$

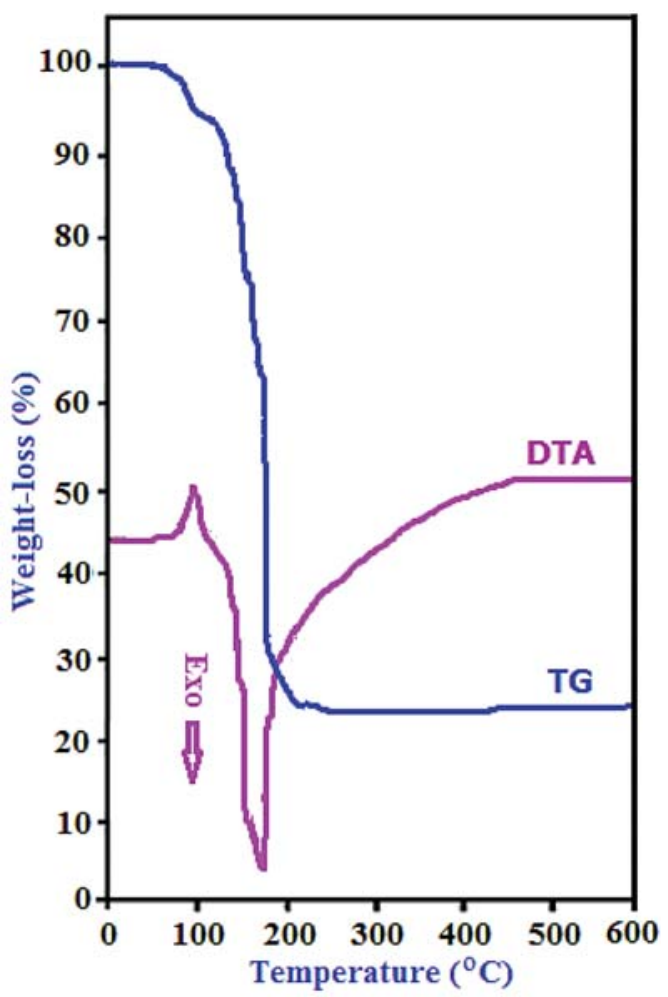

Figure 1. TG and DTA curves of the $\left[\mathrm{Co}\left(\mathrm{NH}_{3}\right)_{5}\left(\mathrm{H}_{2} \mathrm{O}\right)\right]\left(\mathrm{NO}_{3}\right)_{3}$ complex. which is consistent with the theoretical value $(76.95 \%)$ calculated for the formation of $\mathrm{Co}_{3} \mathrm{O}_{4}$ from the complex. Although the exact reaction is unclear and intermediates and gaseous products had not been identified directly, based on the above TG/DTA results and previously reported data, ${ }^{55,56}$ the explosive decomposition of the complex resulted in the solid $\mathrm{Co}_{3} \mathrm{O}_{4}$ and probably gaseous products (i.e. $\mathrm{NH}_{3}, \mathrm{~N}_{2}, \mathrm{NO}, \mathrm{N}_{2} \mathrm{O}$ and $\mathrm{H}_{2} \mathrm{O}$ ) can be expressed as follows: $3\left[\mathrm{Co}\left(\mathrm{NH}_{3}\right)_{5}\left(\mathrm{H}_{2} \mathrm{O}\right)\right]\left(\mathrm{NO}_{3}\right)_{3}(\mathrm{~s}) \rightarrow \mathrm{Co}_{3} \mathrm{O}_{4}(\mathrm{~s})+$ gaseous products (i.e. $2 \mathrm{NH}_{3}(\mathrm{~g}), 19.5 \mathrm{H}_{2} \mathrm{O}(\mathrm{g})+9.25 \mathrm{~N}_{2}(\mathrm{~g})+$ $1.5 \mathrm{NO}(\mathrm{g})$ and $\left.\mathrm{N}_{2} \mathrm{O}(\mathrm{g})\right)$

The FT-IR spectra of the $\left[\mathrm{Co}\left(\mathrm{NH}_{3}\right)_{5}\left(\mathrm{H}_{2} \mathrm{O}\right)\right]\left(\mathrm{NO}_{3}\right)_{3}$ complex and its decomposition products at the selected temperatures were shown in Figure 2. As shown in Figure 2(a), the FT-IR spectrum of the complex shows the characteristic bands of the $\mathrm{NH}_{3}$ and $\mathrm{NO}_{3}$ groups ligands at about 3500-3000, 1600-1500, 1450-1250, 1050 and 650 $\mathrm{cm}^{-1} .{ }^{57}$ For the sample calcined at $150{ }^{\circ} \mathrm{C}$ in Figure 2(b), most of the bands associated with the complex disappeared and two weak bands of the spinel-type $\mathrm{Co}_{3} \mathrm{O}_{4}$ structure at about 660 and $560 \mathrm{~cm}^{-1}$ are observed. The former band is characteristic of $\mathrm{Co}^{3+}-\mathrm{O}$ vibration in an octahedral site, and the later one is attributable to the $\mathrm{Co}^{2+}-\mathrm{O}$ vibration in a tetrahedral site of the $\mathrm{Co}_{3} \mathrm{O}_{4}$ lattice. ${ }^{32}$ As can be seen in Figure 2(c), the sample decomposed at $175^{\circ} \mathrm{C}$ shows only two characteristic bands of the $\mathrm{Co}_{3} \mathrm{O}_{4}$ phase, confirming the complete decomposition of the complex to pure $\mathrm{Co}_{3} \mathrm{O}_{4}$ phase.

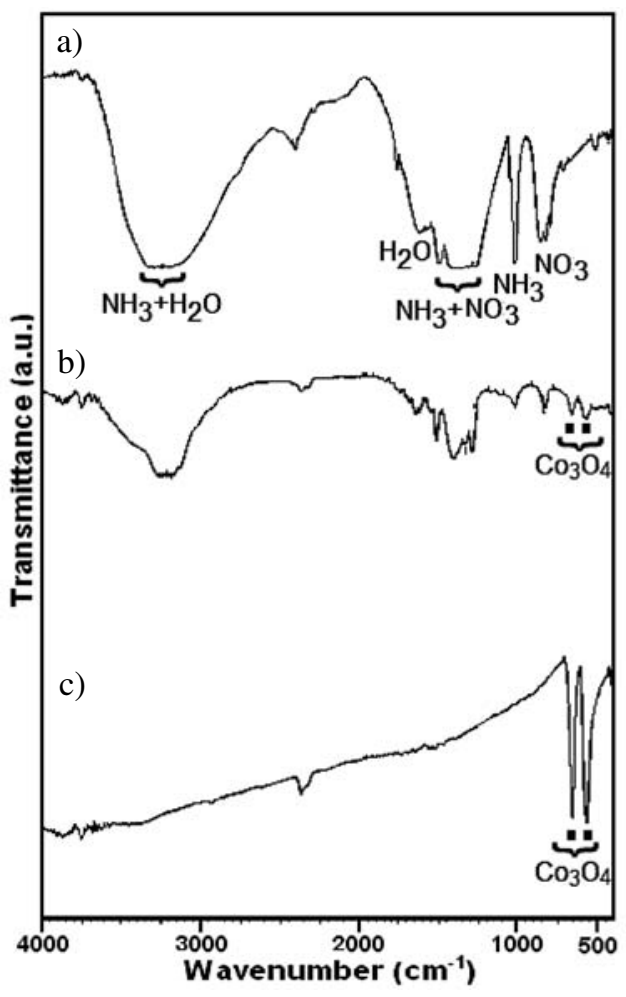

Figure 2. FT-IR spectra of (a) $\left[\mathrm{Co}\left(\mathrm{NH}_{3}\right)_{5}\left(\mathrm{H}_{2} \mathrm{O}\right)\right]\left(\mathrm{NO}_{3}\right)_{3}$ complex and its decomposition product at (b) $150{ }^{\circ} \mathrm{C}$ and (c) $175^{\circ} \mathrm{C}$. 
Figure 3 shows the XRD patterns of the samples calcined at 150 and $175{ }^{\circ} \mathrm{C}$. The XRD pattern of sample decomposed at $150{ }^{\circ} \mathrm{C}$ in Figure 3(a) exhibits weak diffraction peaks with $2 \theta$ values at $19.50^{\circ}, 31.37^{\circ}, 37.02^{\circ}$, $39.10^{\circ}, 44.97^{\circ}, 55.84^{\circ}, 59.58^{\circ}, 65.44^{\circ}$ and $77.65^{\circ}$. These diffraction peaks can be indexed to the crystalline cubic phase $\mathrm{Co}_{3} \mathrm{O}_{4}$ with lattice constant of $\mathrm{a}=8.076 \AA$ and $\mathrm{a}$ space group of $\mathrm{Fd} 3 \mathrm{~m}$, which are in agreement with the reported values (JCPDS Card No. 76-1802). This result confirms that the $\mathrm{Co}_{3} \mathrm{O}_{4}$ phase started to appear at $150{ }^{\circ} \mathrm{C}$, as indicated by the FT-IR result. As can be seen in Figure $3(\mathrm{~b})$, the intensity of the characteristic peaks of the $\mathrm{Co}_{3} \mathrm{O}_{4}$ phase markedly increases with increasing the decomposition temperature to $175{ }^{\circ} \mathrm{C}$. This finding confirms that the complex was completely decomposed to the $\mathrm{Co}_{3} \mathrm{O}_{4}$ phase at $175{ }^{\circ} \mathrm{C}$. No impurity diffraction peaks were detected in the patterns, indicating that the product is of high purity. Furthermore, the diffraction peaks are markedly broadened due to the small size effect of the particles. The average sizes of the $\mathrm{Co}_{3} \mathrm{O}_{4}$ particles was calculated by the Debye-Scherrer equation: ${ }^{58} \mathrm{D}_{\mathrm{XRD}}=0.9 \lambda /(\beta \cos \theta)$ where $\mathrm{D}_{\mathrm{XRD}}$ is the average crystalline size, $\lambda$ is the wavelength of $\mathrm{Cu}$ $\mathrm{K} \alpha, \beta$ is the full width at half maximum (FWHM) of the diffraction peak and $\theta$ is the Bragg's angle. The average size of the nanopartricles calculated using the most intense peak (311) at $2 \theta=36.26^{\circ}$ is approximately $20 \mathrm{~nm}$. This value is in accordance with TEM observations (discussed below).

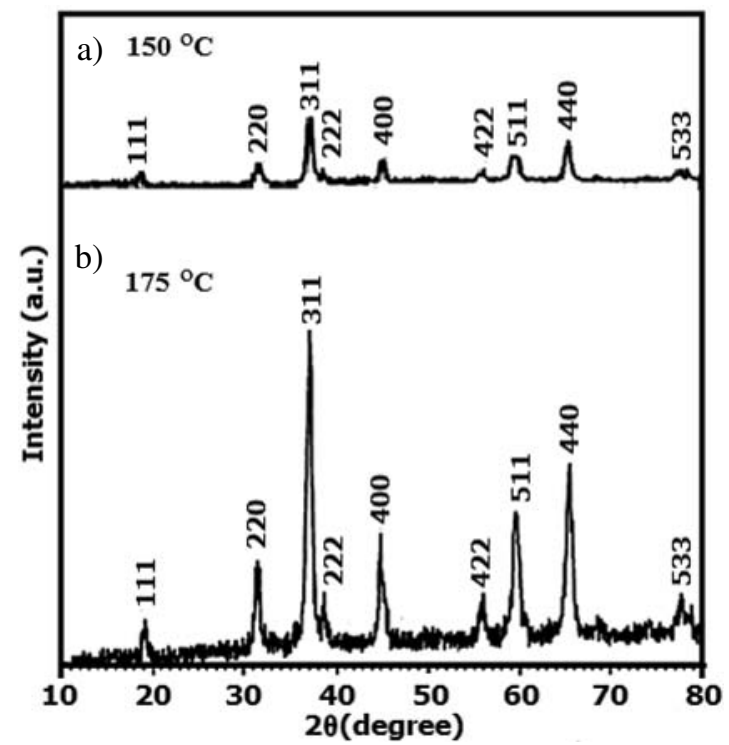

Figure 3. The XRD patterns for the decomposition product of $\left[\mathrm{Co}\left(\mathrm{NH}_{3}\right)_{5}\left(\mathrm{H}_{2} \mathrm{O}\right)\right]\left(\mathrm{NO}_{3}\right)_{3}$ complex at (a) $150{ }^{\circ} \mathrm{C}$ and (b) $175^{\circ} \mathrm{C}$.

It is known that Raman scattering is very sensitive to the microstructure of nanocrystalline materials, it is also used here to clarify the structure of the $\mathrm{Co}_{3} \mathrm{O}_{4}$ nanoparticles. As shown in Fig. 3, the Raman spectrum of the $\mathrm{Co}_{3} \mathrm{O}_{4}$ nanoparticles in the range of $400-800 \mathrm{~nm}$ shows four obvious peaks located at around 467, 508,610, and $675 \mathrm{~cm}^{-1}$, corresponding to the four Raman-active modes of $\mathrm{Co}_{3} \mathrm{O}_{4}$. The Raman bands with medium intensity located at 467 and $508 \mathrm{~cm}^{-1}$ have the Eg and $\mathrm{F}_{2} \mathrm{~g}^{(2)}$ symmetry, respectively, whereas the weak band located at $610 \mathrm{~cm}^{-1}$ has the $\mathrm{F}_{2} \mathrm{~g}^{(1)}$ symmetry. ${ }^{40}$ The strong band at about $675 \mathrm{~cm}^{-1}$ is attributed to the characteristics of the octahedral sites $\left(\mathrm{Co}^{\mathrm{III}} \mathrm{O}_{6}\right)$, which is assigned to the $\mathrm{A}_{1} \mathrm{~g}$ species in the $\mathrm{O}_{\mathrm{h}}$ spectroscopic symmetry [40]. The Raman shifts are consistent with those of pure crystalline $\mathrm{Co}_{3} \mathrm{O}_{4}$, indicating that the $\mathrm{Co}_{3} \mathrm{O}_{4}$ nanoparticles have a similar crystal structure of the bulk $\mathrm{Co}_{3} \mathrm{O}_{4} \cdot{ }^{59}$ However, compared with that for bulk $\mathrm{Co}_{3} \mathrm{O}_{4}$, the peak positions of the four active modes of $\mathrm{Eg}$, $\mathrm{F}_{2} \mathrm{~g}^{(2)}, \mathrm{F}_{2} \mathrm{~g}^{(1)}$ and $\mathrm{A}_{1} \mathrm{~g}$ shift to low wavenumbers about 15 , 13,6 and $16 \mathrm{~cm}^{-1}$, respectively. ${ }^{59}$ This phenomenon is attributed to the optical phonon confinement effect in nanostructures that can cause uncertainty in the phonon wave vectors and then a downshift of the Raman peaks. ${ }^{60}$

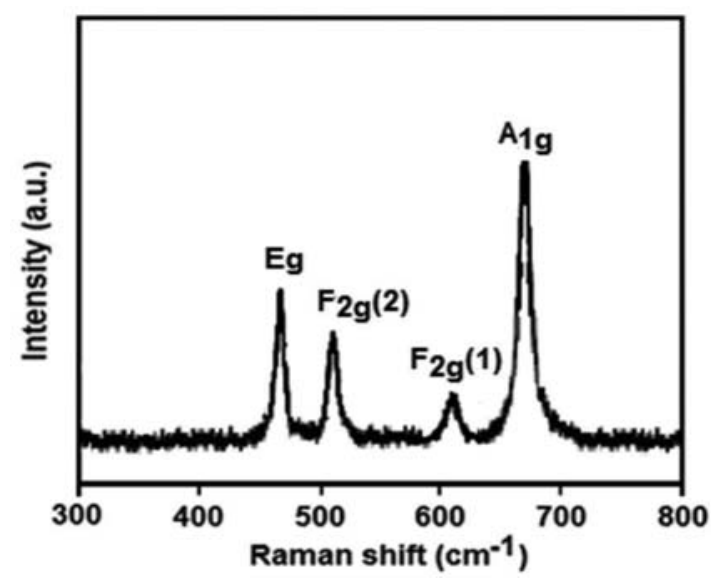

Figure 4. Raman spectrum of the $\mathrm{Co}_{3} \mathrm{O}_{4}$ nanoparticles.

The morphology of $\mathrm{Co}_{3} \mathrm{O}_{4}$ nanoparticles was investigated by SEM. Figure 5 shows the SEM image of the as-prepared $\mathrm{Co}_{3} \mathrm{O}_{4}$ nanoparticles. From the SEM image, it is clearly evident that the product consists of extremely fine particles with sphere-like morphologies that appreciably aggregated as clusters due to the extremely small dimensions and high surface energy of the obtained nanoparticles. The SEM image shows irregular particle agglomerates of the product, indicating that the synthesized $\mathrm{Co}_{3} \mathrm{O}_{4}$ is actually composed of numerous nanoparticles with a uniform size, and these particles undergo further aggregation to form porous agglomerate structure.

The TEM image and size distribution of the $\mathrm{Co}_{3} \mathrm{O}_{4}$ nanoparticles are shown in Figure 6. The TEM sample was prepared by dispersing the powder in ethanol by ultrasonic vibration. It can be seen from Figure 6(a) that the nanoparticles show approximately sphere-like morphologies with a uniform size. Because of the small dimensions 


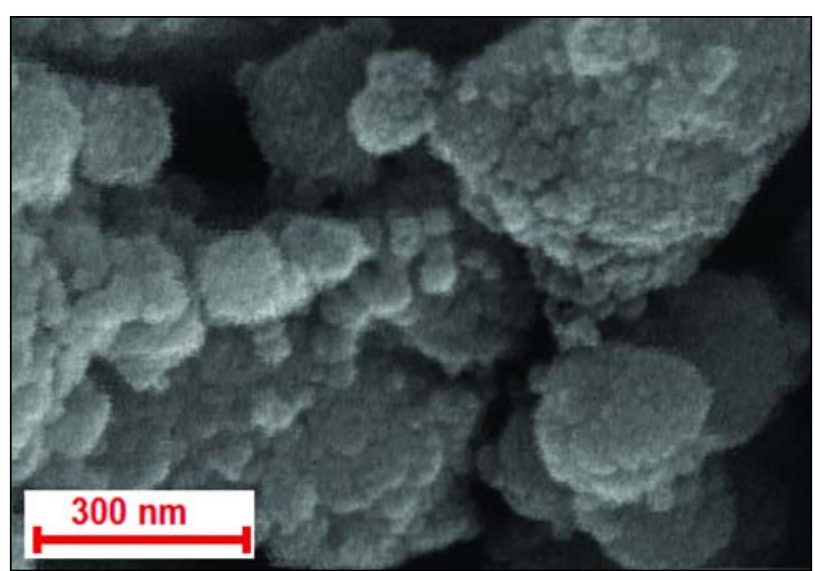

Figure 5. SEM image of the $\mathrm{Co}_{3} \mathrm{O}_{4}$ nanoparticles.

and high surface energy of the particles, it is easy for them to aggregate as seen in Figure 6(a). We also can find from this figure that the morphology of the particles is almost homogeneous. To investigate the size distribution of the $\mathrm{Co}_{3} \mathrm{O}_{4}$ nanoparticles, the particle size histogram was also determined from the TEM image. Figure 6(b) shows the particle size distribution of the $\mathrm{Co}_{3} \mathrm{O}_{4}$ particles. It is clear that the diameter sizes of the $\mathrm{Co}_{3} \mathrm{O}_{4}$ nanoparticles are approximately in the range of 5 to $30 \mathrm{~nm}$ with a narrow size distribution. The average particle size is $17.5 \mathrm{~nm}$, which is in agreement with the result calculated for the half-width of diffraction peaks using the Scherrer's formula, allowing for experimental error.

The chemical purity and stoichiometry of the product were also examined by EDX analysis. Figure 7 shows the EDX spectrum of the $\mathrm{Co}_{3} \mathrm{O}_{4}$ nanoparticles prepared by the decomposition of $\left[\mathrm{Co}\left(\mathrm{NH}_{3}\right)_{5}\left(\mathrm{H}_{2} \mathrm{O}\right)\right]\left(\mathrm{NO}_{3}\right)_{3}$ at

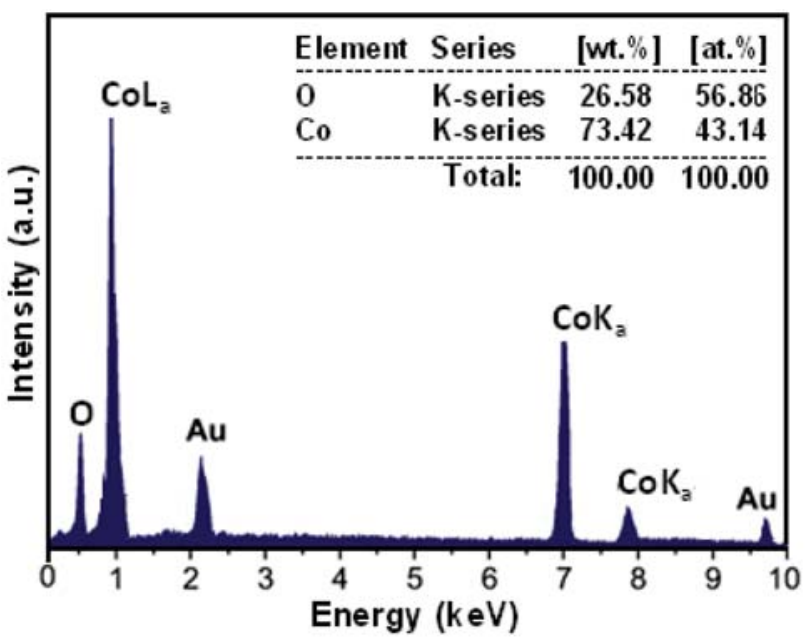

Figure 7. EDX spectrum of the $\mathrm{Co}_{3} \mathrm{O}_{4}$ nanoparticles.

$175{ }^{\circ} \mathrm{C}$. Only oxygen and cobalt elements existed in the product. The atomic percentages of $\mathrm{Co}$ and $\mathrm{O}$ were found to be $43.14 \%$ and $56.86 \%$, respectively, which is near to the theoretical ratio (3:4) of $\mathrm{Co}_{3} \mathrm{O}_{4}$. The Au peaks at about 2.2 and $9.75 \mathrm{keV}$ correspond to the TEM holding grid. No other elements can be detected, indicating the high purity of the $\mathrm{Co}_{3} \mathrm{O}_{4}$ nanoparticles.

To determine the magnetic properties, the hysteresis loop of the $\mathrm{Co}_{3} \mathrm{O}_{4}$ nanoparticles was measured at room temperature. As shown in Figure 8, the magnetization is approximately linear with the field and it does not attain the saturation even at the applied field of $8 \mathrm{kOe}$. As shown in the inset of Figure 8, a tiny hysteresis loop can be observed with a coercivity of about 135 Oe which is characteristic of weak ferromagnetic behaviour, although bulk $\mathrm{Co}_{3} \mathrm{O}_{4}$ has antifer- a)

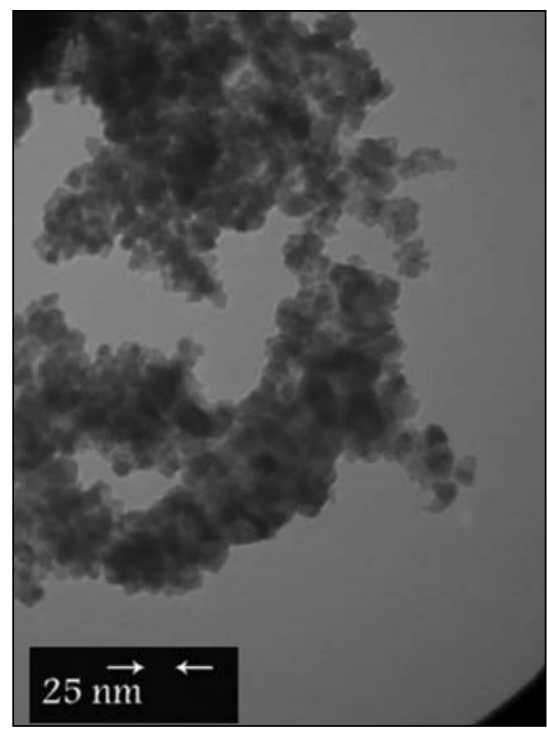

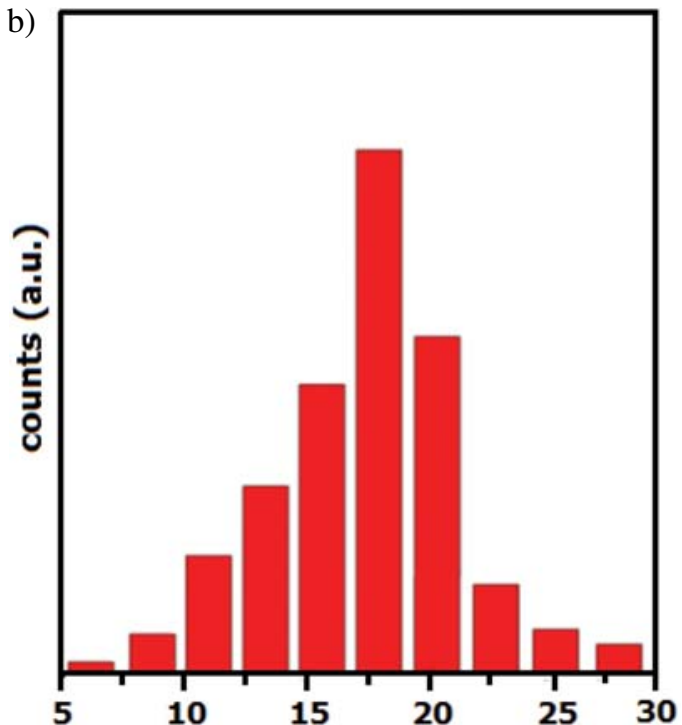

Figure 6. (a) TEM image of the $\mathrm{Co}_{3} \mathrm{O}_{4}$ nanoparticles and (b) Histogram showing the size distribution of the $\mathrm{Co}_{3} \mathrm{O}_{4}$ nanoparticles 


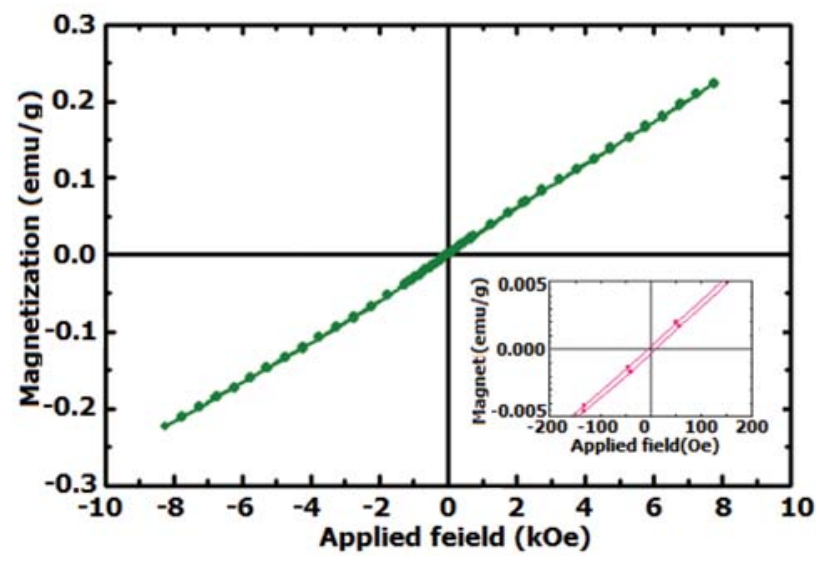

Figure 8. (a) Magnetization curve as a function of applied magnetic field for $\mathrm{Co}_{3} \mathrm{O}_{4}$ nanoparticles at room temperature, and (b) the expansion of magnetization vs. field near the lower applied field.

romagnetic nature. This behavior is similar to that of $\mathrm{Co}_{3} \mathrm{O}_{4}$ nanoparticles obtained by a solvothermal process ${ }^{27}$ and may be explained by uncompensated surface spins and/or finite size effects of the $\mathrm{Co}_{3} \mathrm{O}_{4}$ nanoparticles. ${ }^{60}$

Optical absorption properties of the as-prepared $\mathrm{Co}_{3} \mathrm{O}_{4}$ nanoparticles were investigated at room temperature by UV-vis spectroscopy. As can be seen in Figure 9, the product shows two absorption bands in the wavelength ranges of 200-350 and 380-600 $\mathrm{nm}$. As has been reported in the literatures, ${ }^{16,30}$ these bands can be assigned to the $\mathrm{O}^{2-} \rightarrow \mathrm{Co}^{2+}$ and $\mathrm{O}^{2-} \rightarrow \mathrm{Co}^{3+}$ charge transfer processes, respectively. $\mathrm{Co}_{3} \mathrm{O}_{4}$ is a p-type semiconductor and its band gap, $\mathrm{E}_{\mathrm{g}}$, can be determined by the following equation:

$$
(\alpha h v)^{2}=\mathrm{K}\left(\mathrm{h} v-E_{g}\right)
$$

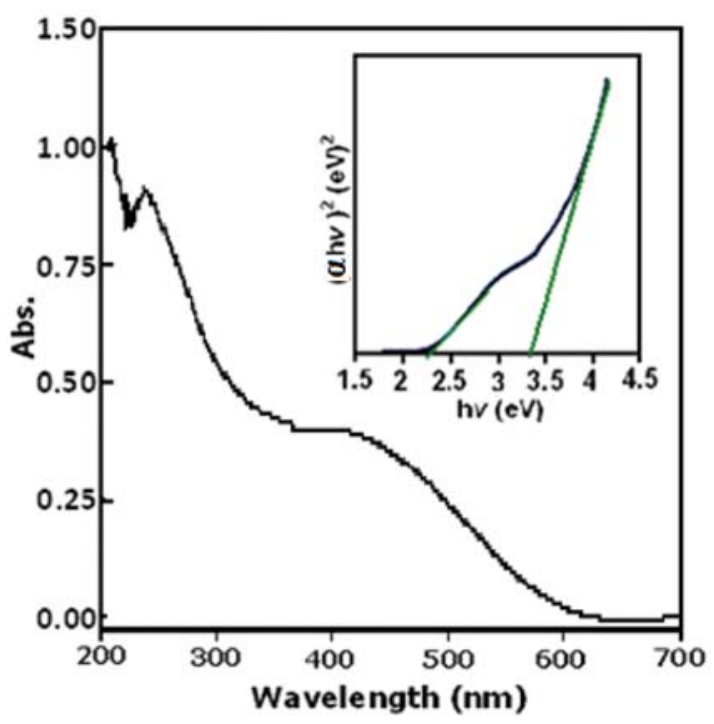

Figure 9. UV-Vis spectrum and $(\alpha \mathrm{h} v)^{2}$-h $v$ curve (inset) of the $\mathrm{Co}_{3} \mathrm{O}_{4}$ nanoparticles.
Where $\mathrm{h} v$ is the photon energy (in $\mathrm{eV}$ ), $\alpha$ is the absorption coefficient, $\mathrm{K}$ is a constant relative to the material. The plot of $(\alpha \mathrm{h} v)^{2}$ versus $h v$ is shown in the inset of Figure 9. The value of $h v$ extrapolated to $(\alpha h v)^{2}=0$ gives an absorption band gap energy $\left(\mathrm{E}_{\mathrm{g}}\right)$. The absorption bands in Figure 9 yield two $\mathrm{E}_{\mathrm{g}}$ values of 3.45 and $2.20 \mathrm{eV}$ for the product which are greater than the bulk $\mathrm{Co}_{3} \mathrm{O}_{4}$ values (2.19 and $1.48 \mathrm{eV}$, respectively). ${ }^{61}$ The increase in the band gaps of the $\mathrm{Co}_{3} \mathrm{O}_{4}$ nanoparticles supports a quantum confinement effect relating to tiny nanoparticles. ${ }^{62,63}$

\section{2. Photocatalytic Activity of the $\mathrm{Co}_{3} \mathrm{O}_{4}$ Nanoparticles}

The photocatalytic activity of the as-synthesized $\mathrm{Co}_{3} \mathrm{O}_{4}$ nanoparticles for the degradation of organic dye such as methylene blue (MB) has been performed under visible light irradiation at room temperature. The UV-vis spectra of $\mathrm{MB}$ aqueous solution in the presence of $\mathrm{Co}_{3} \mathrm{O}_{4}$ nanoparticles photocatalyst and $\mathrm{H}_{2} \mathrm{O}_{2}$ under visible light irradiation $(\lambda>420 \mathrm{~nm})$ over various time intervals are shown in Figure 10. MB dye has a characteristic absorption peak at about $662 \mathrm{~nm}$, which obviously decreases with the increase of irradiation time due to the continuous photocatalytic degradation of MB molecules in the system. After $150 \mathrm{~min}$ irradiation, the absorbance of the MB aqueous solution reaches to less than 0.01 , indicating the complete degradation of MB. Therefore, the photocatalytic experiments show that the as-prepared $\mathrm{Co}_{3} \mathrm{O}_{4}$ nanoparticles have much high visible-light photocatalytic activity.

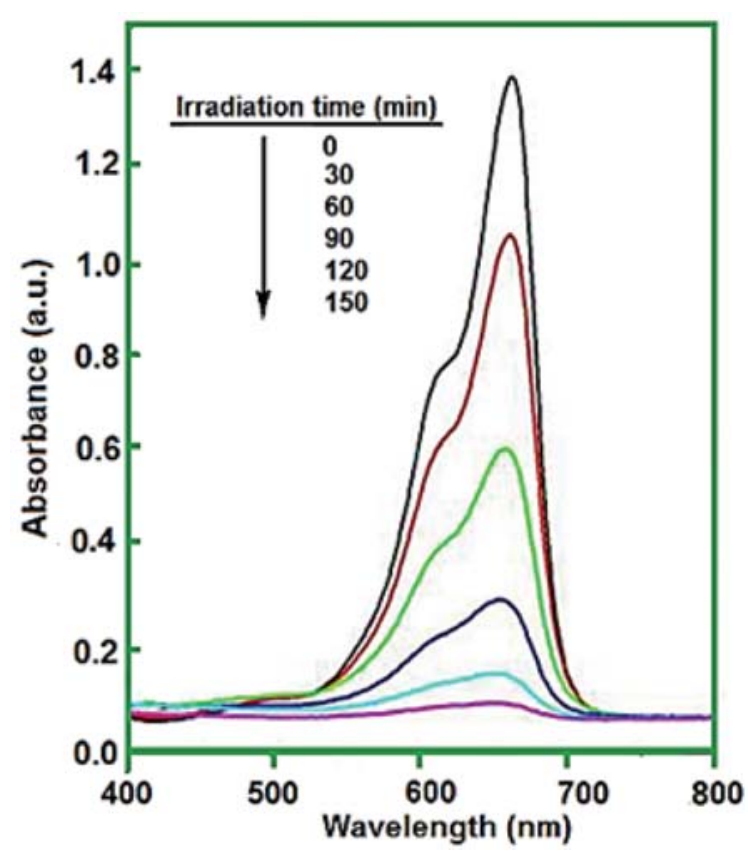

Figure 10. Evolution of UV-vis absorption spectrum of methylene blue (MB) under irradiation at different times using $\mathrm{Co}_{3} \mathrm{O}_{4}$ nanoparticles in the presence of $\mathrm{H}_{2} \mathrm{O}_{2}$. 
Figure 11 shows the degradation rate of $\mathrm{MB}$ dye at different exposure times in the presence $\mathrm{Co}_{3} \mathrm{O}_{4}$ catalyst. $\mathrm{C}_{0}$ is the concentration of dye after the adsorption-desorption equilibrium but before irradiation, and $\mathrm{C}$ is the concentration of dye after different visible light irradiation times. As can be seen in Figure 11, in the absence of $\mathrm{Co}_{3} \mathrm{O}_{4}$ nearly $15 \%$ of the MB molecules are degraded by $\mathrm{H}_{2} \mathrm{O}_{2}$ after irradiation for $150 \mathrm{~min}$ (curve a). The degradation rate of $\mathrm{MB}$ molecules is significantly enhanced when $\mathrm{Co}_{3} \mathrm{O}_{4}$ is added to the dye solution (curve b). Nearly $100 \%$ of $\mathrm{MB}$ is degraded by $\mathrm{Co}_{3} \mathrm{O}_{4}$ nanoparticles in the presence of $\mathrm{H}_{2} \mathrm{O}_{2}$ after irradiation for $150 \mathrm{~min}$. These results can be possibly attributed to the remarkable function of $\mathrm{Co}_{3} \mathrm{O}_{4}$ nanoparticles, which serve as generator of hydroxyl radicals $(\mathrm{OH})$ via photoelectrochemical decomposition of $\mathrm{H}_{2} \mathrm{O}_{2}$ under visible light irradiation. Therefore, the assynthesized $\mathrm{Co}_{3} \mathrm{O}_{4}$ nanoparticles are an excellent photocatalyst in the presence of $\mathrm{H}_{2} \mathrm{O}_{2}$ under visible light irradiation to degrade organic dyes.

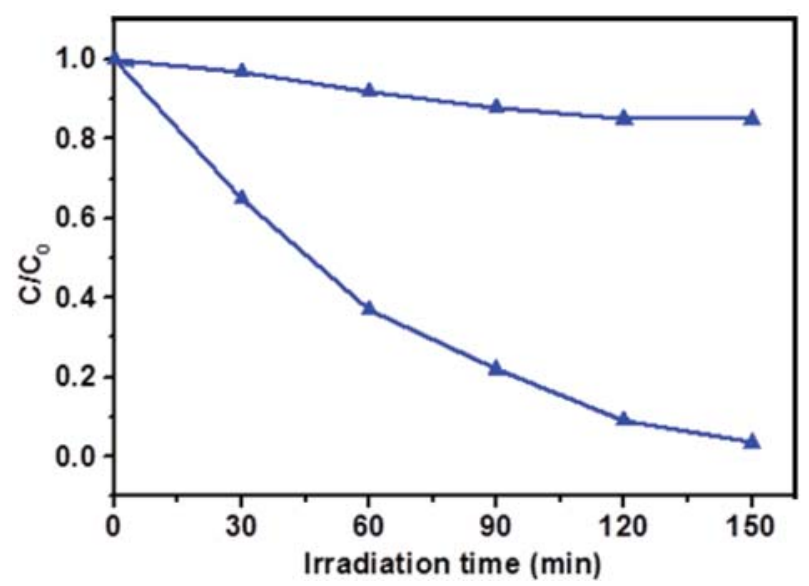

Figure 11. Photocatalytic degradation of $\mathrm{MB}$ in the presence of : (a) $\mathrm{H}_{2} \mathrm{O}_{2}$ and (b) $\mathrm{Co}_{3} \mathrm{O}_{4}+\mathrm{H}_{2} \mathrm{O}_{2}$.

Based on the above results, a possible photocatalytic mechanism of $\mathrm{Co}_{3} \mathrm{O}_{4}$ nanoparticles has been proposed as follows: Upon irradiation with visible light, $\mathrm{Co}_{3} \mathrm{O}_{4}$ nanoparticles particles undergo charge separation, electrons in the valence band of $\mathrm{Co}_{3} \mathrm{O}_{4}$ can be excited to its conduction band $\left(\mathrm{e}_{\mathrm{CB}}^{-}\right)$, causing the generation of holes in the valance band $\left(\mathrm{h}^{+}{ }_{\mathrm{VB}}\right)$ simultaneously (reaction 1$)$. Then, the $\mathrm{e}^{-}{ }_{\mathrm{CB}}$ can activate the $\mathrm{H}_{2} \mathrm{O}_{2}$ to generate the ${ }^{\circ} \mathrm{OH}$ and $\mathrm{OH}^{-}$(reaction (2)). Thus, the $\mathrm{OH}^{*}$ generated from reaction (2) is the main factor for photodegradation of the dye.

$$
\begin{aligned}
& \mathrm{Co}_{3} \mathrm{O}_{4}+\mathrm{hv} \rightarrow \mathrm{e}_{\mathrm{CB}}^{-}+\mathrm{h}^{+}{ }_{\mathrm{VB}} \\
& \mathrm{H}_{2} \mathrm{O}_{2}+\mathrm{e}_{\mathrm{CB}}^{-} \rightarrow \mathrm{OH}+\mathrm{OH}^{-} \\
& \mathrm{MB}+\mathrm{OH} \rightarrow \text { degradation products } \\
& \left(\mathrm{CO}_{2}, \mathrm{H}_{2} \mathrm{O}, \mathrm{NO}_{3}, \text { etc }\right)
\end{aligned}
$$

\section{Conclusions}

In conclusion, $\mathrm{Co}_{3} \mathrm{O}_{4}$ nanoparticles with an average particle size of $17.5 \mathrm{~nm}$ have been successfully prepared by the thermal decomposition of the $\left[\mathrm{Co}\left(\mathrm{NH}_{3}\right)_{5}\left(\mathrm{H}_{2} \mathrm{O}\right)\right]\left(\mathrm{NO}_{3}\right)_{3}$ as a new precursor at $175{ }^{\circ} \mathrm{C}$. The formation of the $\mathrm{Co}_{3} \mathrm{O}_{4}$ nanoparticles from the precursor complex can be explained through a redox reaction between the $\mathrm{NH}_{3}$ ligands as the reducing agent and the $\mathrm{NO}_{3}$ ions as the oxidizing agent. This method yields sphere-like $\mathrm{Co}_{3} \mathrm{O}_{4}$ nanoparticles with a narrow size distribution and a weak ferromagnetic behavior. The estimated optical absorption band gaps of the $\mathrm{Co}_{3} \mathrm{O}_{4}$ nanoparticles are relatively blue-shifted, compared with the values for the bulk sample. The as-prepared $\mathrm{Co}_{3} \mathrm{O}_{4}$ nanoparticles exhibit an excellent photocatalytic activity for the $\mathrm{H}_{2} \mathrm{O}_{2}$-assisted degradation of MB dye under visible light irradiation.

\section{Acknowledgements}

The authors are grateful to the Lorestan University Research Council and Iran Nanotechnology Initiative Council (INIC) for financial support.

\section{References}

1. K. J. Klabunde, R. M., Nanoscale Materials in Chemistry, 2nd edn. Wiley, New York, 2012.

2. W. Y. Li, L. N. Xu, J. Chen, Adv. Funct. Mater. 2005, 15, 851- 857. http://dx.doi.org/10.1002/adfm.200400429

3. R. Wu, J. Wu, M. Yu, T. Tsai, C. Yeh, Sens. Actu. B: Chem. 2008, 131, 306-312. http://dx.doi.org/10.1016/j.snb.2007.11.033

4. A. Askarinejad, M. Bagherzadeh, A. Morsali, Appl. Surface Sci. 2010, 256, 6678-6682.

http://dx.doi.org/10.1016/j.apsusc.2010.04.069

5. T. E. Davies, T. Garcia, B. Solsona, S. H. Taylor, Chem. Commun. 2006, 32, 3417-3419.

http://dx.doi.org/10.1039/B606973H

6. V. R. Mate, M. Shirai, C. V. Rode, Catal. Commun. 2013, 33, 66-69. http://dx.doi.org/10.1016/j.catcom.2012.12.015

7. T. Maruyama, S. Arai, J. Electrochem. Soc. 1996, 143, 1383-1386. http://dx.doi.org/10.1149/1.1836646

8. N. Du, H. Zhang, B. D. Chen, J. B. Wu, X. Y. Ma, Z. H. Liu, Y. Q. Zhang, D. R. Yang, X. H. Huang, J. P. Tu, Adv. Mater. 2007, 19, 4505-4509.

http://dx.doi.org/10.1002/adma.200602513

9. X. W. Lou, D. Deng, J. Y. Lee, L. A. Archer, Adv. Mater. 2008, 20, 258-262. http://dx.doi.org/10.1002/adma.200702412

10. S. L. Chou, J. Z. Wang, H. K. Liu, S. X. Dou, J. Power Sources 2008, 182, 359-364.

http://dx.doi.org/10.1016/j.jpowsour.2008.03.083

11. Y. G. Li, B. Tan, Y. Y. Wu, Nano Lett. 2008, 8, 265-270. 
http://dx.doi.org/10.1021/n10725906

12. R. M. Wang, C. M. Liu, H. Z. Zhang, C. P. Chen, L. Guo, H. B. Xu, S. H. Yang, Appl. Phys. Lett. 2004, 85, 2080-2082. http://dx.doi.org/10.1063/1.1789577

13. S. A. Makhlouf, J. Magn. Magn. Mater. 2002, 246, 184-190. http://dx.doi.org/10.1016/S0304-8853(02)00050-1

14. X. Lou, J. Han, W. Chu, X. Wang, Q. Cheng, Mater. Sci. Eng. B 2007, 137, 268-271.

http://dx.doi.org/10.1016/j.mseb.2006.12.002

15. T. Warang, N. Patel, A. Santini, N. Bazzanella, A. Kale, A. Miotello, Appl. Catal. A: Gen. 2012, 423-424, 21- 27.

16. L. Sun, H. Li, L. Ren, C. Hu, Solid State Sci. 2009, 11, 108112.

http://dx.doi.org/10.1016/j.solidstatesciences.2008.05.013

17. Y. Chen, Y. Zhang, S. Fu, Mater. Lett. 2007, 61, 701-705. http://dx.doi.org/10.1016/j.matlet.2006.05.046

18. T. Lai, Y. Lai, C. Lee, Y. Shu, C. Wang, Catal. Today 2008 , 131, 105-110. http://dx.doi.org/10.1016/j.cattod.2007.10.039

19. W. W. Wang, Y. J. Zhu, Mater. Res. Bull. 2005, 40, 19291935. http://dx.doi.org/10.1016/j.materresbull.2005.06.004

20. L. Li, Y. Chu, Y. Liu, J. L. Song, D. Wang, X.W. Du, Mater. Lett. 2008, 62, 1507-1510.

http://dx.doi.org/10.1016/j.matlet.2007.09.012

21. J. Du, L. Chai, G. Wang, K. Li, Y. Qian, Aust. J. Chem. 2008, 61, 153-158. http://dx.doi.org/10.1071/CH07186

22. R. M. Wang, C. M. Liu, H. Z. Zhang, C. P. Chen, L. Guo, H. B. Xu, S. H. Yang, Appl. Phys. Lett. 2004, 85, 2080-2082. http://dx.doi.org/10.1063/1.1789577

23. Y. Li, J. Zhao, Y. Dan, D. Ma, Y. Zhao, S. Hou, H. Lin, Z. Wang, Chem. Eng. J. 2011, 166, 428-434. http://dx.doi.org/10.1016/j.cej.2010.10.080

24. H. Sun, M. Ahmad, J. Zhu, Electrochim. Acta 2013, 89, 199 205. http://dx.doi.org/10.1016/j.electacta.2012.10.116

25. M. Ren, S. Yuan, L. Su, Z. Zhou, Solid State Sci. 2012, 14, 451-455. http://dx.doi.org/10.1016/j.solidstatesciences.2012.01.011

26. L. X. Yang, Y.J. Zhu, L. Li, L, Zhang, H. Tong, W. W. Wang, Eur. J. Inorg. Chem. 2006, 23, 4787-4792. http://dx.doi.org/10.1002/ejic.200600553

27. J. Ma, S. Zhang, W. Liu, Y. Zhao, J. Alloys Compd. 2010, 490, 647-651.

http://dx.doi.org/10.1016/j.jallcom.2009.10.126

28. E. Lester, G. Aksomaityte, J. Li, S. Gomez, Prog. Cryst. Growth Charact. Mater. 2012, 58, 3-13. http://dx.doi.org/10.1016/j.pcrysgrow.2011.10.008

29. J. Jiu, Y. Ge, X. Li, X, L. Nie, Mater. Lett. 2002, 54, 260 263. http://dx.doi.org/10.1016/S0167-577X(01)00573-0

30. F. Gu, C. Li, Y. Hu, L. Zhang, J. Cryst. Growth 2007, 304, 369-373. http://dx.doi.org/10.1016/j.jcrysgro.2007.03.040

31. M. C. Gardey-Merin, O. M. Palermo, R. Belda, M. E. Fernández de Rapp, G. E.Lascalea, P. G. Vázquez, Proced. Mater. Sci. 2012, 1, 588-593. http://dx.doi.org/10.1016/j.mspro.2012.06.079

32. L. H. Ai, J. Jiang, Powder Tech. 2009, 195, 11-14. http://dx.doi.org/10.1016/j.powtec.2009.05.006
33. L. Li, J. Ren, Mater. Res. Bull. 2006, 41, 2286-2290. http://dx.doi.org/10.1016/j.materresbull.2006.04.022

34. A. S. Bhatt, D. K. Bhat, C. W. Tai, M. S. Mater. Chem. Phys. 2011, 125, 347-350. http://dx.doi.org/10.1016/j.matchemphys.2010.11.003

35. M. E. Baydi, G. Poillerat, J. L. Rehspringer, J. L. Gautier, J. F. Koenig, P. Chartier, J. Solid State Chem. 1994, 109, 281-288. http://dx.doi.org/10.1006/jssc.1994.1105

36. D. Y. Kim, S. H. Ju, H. Y. Koo, S. K. Hong, Y. C. Kangf, J. Alloys Compd. 2006, 417, 254-258. http://dx.doi.org/10.1016/j.jallcom.2005.09.013

37. R. V. Kumar, Y. Diamant, A. Gedanken, Chem. Mater. 2000 , 12, 2301-2305. http://dx.doi.org/10.1021/cm000166z

38. K. Sinko, G. Szabo, M. Zrinyi, J. Nanosci. Nanotechnol. 2011, 11, 1-9. http://dx.doi.org/10.1166/jnn.2011.3875

39. D. Zou, C. Xu, H. Luo, L. Wang, T. Ying, Mater. Lett. 2008, 62, 1976-1978. http://dx.doi.org/10.1016/j.matlet.2007.10.056

40. J. Jiang, L. Li, Mater. Lett. 2007, 6, 4894-4896. http://dx.doi.org/10.1016/j.matlet.2007.03.067

41. S. Fan, X. Liu, Y. Li, E. Yan, C. Wang, J. Liu, Y. Zhang, Mater. Lett. 2013, 91, 291-293 http://dx.doi.org/10.1016/j.matlet.2012.10.008

42. E. Traversa, M. Sakamoto, Y. Sadaoka, Part. Sci. Technol. 1998, 16, 185-214. http://dx.doi.org/10.1080/02726359808906794

43. S. Farhadi, N. Rashidi, Polyhedron 2010, 29, 2959-2965. http://dx.doi.org/10.1016/j.poly.2010.08.019

44. S. Farhadi, Z. Roostaei-Zaniyani, Polyhedron 2011, 30, 1244-1249. http://dx.doi.org/10.1016/j.poly.2011.01.028

45. M. Salavati-Niasari, F. Davar, Mater. Lett. 2009, 63, 441443. http://dx.doi.org/10.1016/j.matlet.2008.11.023

46. M. Y. Masoomi, A. Morsali, Coord. Chem. Rev. 2012, 256, 2921-2943. http://dx.doi.org/10.1016/j.ccr.2012.05.032

47. L. Ren, P. Wang, Y. Han, C. Hu, B. Wei, Mater. Phys. Lett. 2009, 476, 78-83.

48. F. Mohandes, F. Davar, M. Salavati-Niasari, J. Magn. Magn. Mater. 2010, 322, 872-877. http://dx.doi.org/10.1016/j.jmmm.2009.11.019

49. M. Salavati-Niasari A. Khansari, F. Davar, Inorg. Chim. Acta 2009, 362, 4937-4942.

50. K. Thangavelu, K. Parameswari, K. Kuppusamy, Y. Haldorai, Y, Mater. Lett. 2011, 65, 1482-1484. http://dx.doi.org/10.1016/j.matlet.2011.02.047

51. S. Farhadi, J. Safabakhsh, J. Alloys Compd. 2012, 515, 180185. http://dx.doi.org/10.1016/j.jallcom.2011.11.135

52. S. Farhadi, K. Pourzare, Mater. Res. Bull. 2012, 47, 15501556. http://dx.doi.org/10.1016/j.materresbull.2012.02.028

53. S. Farhadi, K. Pourzare, Polyhedron 2014, 67, 104-110. http://dx.doi.org/10.1016/j.poly.2013.08.069

54. G. Schlesssinger, Inorg. Synth. 1953, 4, 171-174. http://dx.doi.org/10.1002/9780470132357.ch56

55. W. W. Wendlandt, J. Inorg. Nucl. Chem. 1963, 25, 545-551. http://dx.doi.org/10.1016/0022-1902(63)80239-0

56. M. Liszka-Skoczylas, E. Mikuli, J. Szklarzewicz, J. Hetmanczyk, Thermochim. Acta 2009, 496, 38-44. 
http://dx.doi.org/10.1016/j.tca.2009.06.017

57. K. Nakamoto, Infrared and Raman Spectra of Inorganic and Coordination Compounds, Part B: Applications in Coordination, Organometallic, and Bioinorganic Chemistry, sixth ed., Wiley, New York, 2009.

58. H. P. Klug, L. E. Alexander, X-ray Diffraction Procedures, second ed., Wiley, New York, 1964.

59. V. G. Hadjiev, M. N. Iliev, I. V. Vergilov, J. Phys. C: Solid State Phys. 1988, 21, L199-L201.

http://dx.doi.org/10.1088/0022-3719/21/7/007
60. M. Han, W. Zhang, N. Shi, J. Li, Z. Xu, Chin. J. Inorg. Chem. 2008, 24, 797-802.

61. Y. Qi, Y. Zhao, Z. Wu, Mater. Chem. Phys. 2008, 110, 457462. http://dx.doi.org/10.1016/j.matchemphys.2008.03.001

62. X. P. Shen, H. J. Miao, H. Zhao, Z. Xu, Appl. Phys. A: Mater. Sci. Process 2008, 91, 47-51. http://dx.doi.org/10.1007/s00339-007-4361-6

63. P. Deka, R. C. Deka, P. Bharali, New J. Chem., 2016, 40, 348-357. http://dx.doi.org/10.1039/C5NJ02515J

\section{Povzetek}

Raziskovali smo termični razpad trdnega prekurzurja $\left[\mathrm{Co}\left(\mathrm{NH}_{3}\right)_{5}\left(\mathrm{H}_{2} \mathrm{O}\right)\right]\left(\mathrm{NO}_{3}\right)_{3}$. S termično analizo (TG/DTA) smo ugotovili, da pri razmeroma nizkih temperaturah $\left(175^{\circ} \mathrm{C}\right)$ kompleks razpade do nanodelcev $\mathrm{Co}_{3} \mathrm{O}_{4}$ brez uporabe toksičnih topil ali zapletene opreme. Dobljeni produkt smo karakterizirali z rentgensko praškovno difrakcijo (XRD), infrardečo spektroskopijo (FT-IR), Ramansko spektroskopijo, vrstično elektronsko mikroskopijo (SEM), presevno elektronsko mikroskopijo (TEM) energijsko disperzivno rentgensko spektroskopijo (EDX). Optične in magnetne lastnosti produkta pa smo preučevali z UV-Vis spektroskopijo in magnetometer z vibrirajočim vzorcem (VSM). Na podlagi rezultatov FT-IR, XRD in EDX analiz smo ugotovili, da je dobljeni product zelo čist $\mathrm{Co}_{3} \mathrm{O}_{4}$, s kubično spinelno strukturo. SEM in TEM posnetki kažejo, da imajo nanodelci $\mathrm{Co}_{3} \mathrm{~F}_{4}$ sferično morfologijo. Optični absorpcijski spektri nanodelcev $\mathrm{Co}_{3} \mathrm{~F}_{4}$ so pokazali dve energijski špranji (band gap) pri 2,20 eV in 3,45 eV, s čimer smo tudi potrdili polprevodniške lastnosti materiala. Magnetne meritve so pokazale šibko feromagnetno ureditev pri sobni temperature. $\mathrm{S}$ fotokatalitičnim razpadom barvila metilen modro smo prikazali, da imajo tako pripravljeni nanodelci $\mathrm{Co}_{3} \mathrm{O}_{4}$ dobro fotokatalitično aktivnost. 